\title{
Reflections on the 2018 Decade Award The Meaning and Dynamics of Corporate Social Responsibility
}

Matten, Dirk ; Moon, Jeremy

Document Version

Final published version

Published in:

Academy of Management Review

DOI:

10.5465/amr.2019.0348

Publication date:

2020

License

Unspecified

Citation for published version (APA):

Matten, D., \& Moon, J. (2020). Reflections on the 2018 Decade Award: The Meaning and Dynamics of Corporate Social Responsibility. Academy of Management Review, 45(1), 7-28.

https://doi.org/10.5465/amr.2019.0348

Link to publication in CBS Research Portal

\section{General rights}

Copyright and moral rights for the publications made accessible in the public portal are retained by the authors and/or other copyright owners and it is a condition of accessing publications that users recognise and abide by the legal requirements associated with these rights.

Take down policy

If you believe that this document breaches copyright please contact us (research.lib@cbs.dk) providing details, and we will remove access to the work immediately and investigate your claim. 


\title{
2018 DECADE AWARD INVITED ARTICLE
}

\section{REFLECTIONS ON THE 2018 DECADE AWARD: THE MEANING AND DYNAMICS OF CORPORATE SOCIAL RESPONSIBILITY}

\author{
DIRK MATTEN \\ York University \\ JEREMY MOON \\ Copenhagen Business School
}

\begin{abstract}
We reflect on our 2008 article, "'Implicit' and 'Explicit' CSR: A Conceptual Framework for a Comparative Understanding of Corporate Social Responsibility," first recalling its origins. We contextualize this reflection piece with a stylized interpretation of CSR "then" (the turn of the twenty-first century) and "now" (2019). We then focus on two themes: CSR's meaning and its dynamics. Regarding the meaning of CSR, we indicate the advantages of our capacious CSR definition and elaborate on the underlying theorization of our CSR framework regarding corporations' need for legitimacy with their core stakeholders, societies they operate in, and regulators they are subject to. We propose that the configuration of these legitimacy relationships informs the nature and balance of implicit and explicit CSR. Turning to CSR dynamics, we build on research on the hybridization of implicit and explicit CSR and explore two underlying phenomena-explicitization and implicitization of CSR. We conceptualize explicitization as the process by which norms and rules associated with implicit CSR are adopted in explicit CSR policies, practices, and strategies. We conceptualize implicitization of CSR as the process by which norms and rules of business responsibility are informed by what were hitherto explicit CSR policies, practices, and strategies of corporations, and are built into general obligations of business.
\end{abstract}

Our reflections on "'Implicit' and 'Explicit' CSR: A Conceptual Framework for a Comparative Understanding of Corporate Social Responsibility" (Matten \& Moon, 2008) were reanimated when the AMR editor's email advising us that the article had won AMR's 2018 Decade Award appeared in our in-boxes. This brought surprise, excitement, and a sense of honor, as well as some puzzlement: "There must be something wrong with the

This invited essay reflects on our 2008 article, "'Implicit' and 'Explicit' CSR: A Conceptual Framework for a Comparative Understanding of Corporate Social Responsibility," given the AMR 2018 Decade Award. We have had positive and challenging reviews of an earlier draft of this essay from Tom Donaldson, Arno Kourula, and Andreas Rasche; feedback and advice on legitimacy from Patrick Haack; feedback from and discussion with Steen Vallentin; and feedback from Andrew Pilkington. We would like to thank those who discussed some of our earlier reflections at the 2017 EGOS Annual Colloquium "Sub-theme 01: Capitalism, Corporations and Society," Copenhagen Business School, and at the 2019 TABEC Conference, Rutgers University (Matten \& Moon, in press). Responsibility for any errors and shortcomings lies with the authors. system?!" Our next reflective mood was one of celebration, and we organized a party at a favorite Chicago jazz bar during the 2018 Academy of Management annual meeting. This brought together colleagues who had suffered the early formulations of our ideas, who had shared in the pleasure of the original publication, or who had simply encouraged our work. The party also brought questions prompting further reflections on the origins of the article:

Q: How did you work on this?

A: We were working together at the International Centre for Corporate Social Responsibility, Nottingham University Business School, which provided a fertile atmosphere for thinking about CSR.

Q: What motivated you?

A: Interesting, since this is a theory paper motivated by our engagement with the world of practice that we witnessed at conferences of European business leaders discussing CSR. We were puzzled by the way these European leaders were defining their responsibilities in ways we had associated with North American business. 
Q: What was the AMR review and revision process like?

A: It seemed a little slow to start with, and we discovered that the paper (it was literally a "paper" submission to the AMR) was lost to Hurricane Katrina! It was found, fortunately (we think via one of the reviewers). The review process was challenging and encouraging, with very helpful guidance from the associate editor, Tom Donaldson.

Given that the article is an institutional one, it was also interesting to reflect on one thing we took for granted: the ability to discuss and ponder our ideas in a bar after work! Neither of us had children at the time. This is not to wish our children away; for from it! Rather, it is to acknowledge the feminist observation that care for family members changes the terms of professional engagement.

We had the opportunity for further reflection on the article in the context of media interviews once the news was out. ${ }^{1}$ We were asked why we thought the article had had such a big impact. We summarized this as follows:

- it enables analysis of CSR in various national settings and provides an explanation of different national approaches;

- in particular, it explains historic differences between U.S. and European CSR;

- it enables analysis of dynamic features of CSR (e.g., reflecting institutional change, specifically globalization); and

- it enables understanding of why European and other non-U.S. companies had recently adopted explicit CSR strategies.

In this reflection piece we augment the analysis of the 2008 article for the purpose of better understanding the meaning and the dynamics of CSR. Understanding the meaning and dynamics of any concept is important for its analysis and communication about that analysis. It is especially important for concepts like CSR, which have been described as "essentially contested" (for the concept in general, see Gallie, 1955-1956; for CSR, see Moon, Crane, \& Matten, 2004, and Okoye, 2009), where there is uncertainty about its meaning and, thus, about distinguishing change in that concept from the emergence of a different concept. Or, more prosaically, there is a problem that CSR "means something but not always the same thing to everybody" (Votaw, 1972: 25). As a result, researchers,

\footnotetext{
${ }^{1}$ See, for instance, https://cbswire.dk/cbs-professors-paper-isthe-most-cited-of-the-decade/; https://yfile.news.yorku.ca/2018/09/ 11/prestigious-award-honour-for-schulich-professor-dirk-matten/.
}

policy makers, and practitioners can be talking past one another about CSR.

This reflection piece continues as follows. First, we provide a stylized interpretation of CSR "then" and "now." This introduces key developments in CSR for those for whom this is not a core research area. It also illustrates the importance of focusing on the meaning and dynamics of CSR, because it details changes in CSR that some analysts describe as inconsistent with earlier definitions of CSR and as altogether different concepts.

Second, we explore the meaning of CSR. We elaborate on the definition of CSR that we adopted in the 2008 article and compare it with other CSR definitions. We rehearse and substantiate the theory underlying our conceptualization of CSR with reference to the need for corporations to secure three sorts of legitimacy: with their own core stakeholders, with the societies they operate in, and with the regulators they are subject to. In this light, we provide further background to our thinking, distinguish it from other approaches, and clarify some misunderstandings about our implicit-explicit CSR fromework.

Third, we show how the meaning of CSR that we adopt, and specifically the implicit-explicit conceptualization, sheds light on dynamic aspects of CSR. We do this by focusing on the "hybridization" of implicit and explicit CSR highlighted by other researchers. We identify two key processes underlying this hybridization. First, we explore the explicitization of CSR, in which norms and rules that had implicitly operated to guide business responsibility to society have become more explicit (i.e., included in individual corporations' explicit CSR). Second, we consider how the implicitization of CSR has caused corporations' explicit policies, strategies, and practices to be reflected in implicit assumptions about CSR in wider norms and regulations operating on corporations. As a result of these dynamics, we suggest that CSR reflects various and varying balances of explicit volition and implicit compliance.

In the discussion and conclusion section we summarize the contributions of this reflection piece, discuss some of their implications, and highlight limitations and avenues for further research.

\section{CSR THEN AND NOW}

Here we compare key characteristics of CSR in the period after the turn of the twenty-first century, when we began to formulate the 2008 article, 
with its current character. This introduces CSR to readers without expertise in the field. It also illustrates the significance of addressing the questions about the meaning of CSR (to distinguish it from other concepts) and about its dynamics (to distinguish "change" from "difference" and to understand the nature and explanation of change). We base this discussion around Table 1.

The first change we observe is in the context of explicit CSR. The 2008 article focused on CSR in the United States and Europe at a time of globalization. Although we made brief reference to CSR elsewhere, we did not envisage the multinational and international spread of CSR as evidenced by the nationalities of UN Global Compact organizations and by the growth of international CSR networks, associations, partnerships, multistakeholder initiatives (MSIs), and standards that companies join/adopt/use as reference points or comply with. While the national level still features prominently (Kolk, Kourula, Pisani, \& Westermann-Behaylo, 2020), CSR is also evidenced internationally in numerous initiatives developed among MNCs seeking to legitimize themselves in home and host countries. One clear implication of this multinationalism and internationalization is that rumors of the "end of CSR" (Fleming \& Jones, 2012) seem exaggerated.

The issue focus of CSR has also changed dramatically (Table 1). CSR issues around the turn of the century chiefly concerned the welfare of core stakeholders (notably, employees and communities; Maignan \& Ralston, 2002; Moon \& Sochacki, 1996; Moore, Richardson, \& Moon, 1985). CSR agendas now reflect the specificities of firm, sector, home, and host country contexts. Two further trends are instructive. First, many CSR issues are concerned with the wider responsibilities that companies take for some of their potential negative impacts in their supply chains and even their value chains (e.g., unsafe working conditions, slavery-like terms of employment, pollution, resource depletion). Second, many companies are increasingly focused on the impacts of their operations on the planet at large (e.g., policies related to climate change, species diversity, natural resource depletion; Bansal \& DesJardine, 2014). Reflecting these developments, the term corporate sustainability has been adopted by some companies, and this has become a research focus in light of the UN Sustainable Development Goals (e.g., Whiteman, Walker, \& Perego, 2013).

There have been important changes in the business status of CSR in the last two decades (Table 1). This has primarily reflected legitimacy strategies in relation to core stakeholders (i.e., expenditures within shareholder tolerance; contributions to communities who, in an industrial context, often included employees). The current business status of CSR more readily reflects corporate legitimacy strategies to societies more

TABLE 1

CSR Then and Now: A Stylized Interpretation of Prevalent Themes

\begin{tabular}{|c|c|c|}
\hline $\begin{array}{l}\text { CSR } \\
\text { Characteristics }\end{array}$ & $\begin{array}{l}\text { Then } \\
\text { (Circa 2000) }\end{array}$ & $\begin{array}{l}\text { Now } \\
\text { (Circa 2020) }\end{array}$ \\
\hline Location & U.S. home, with new shoots in Europe (also Assia) & Multinational, international \\
\hline Issue focus & Issues related to core stakeholders & $\begin{array}{l}\text { Issues related to core stakeholders, whole value } \\
\text { chains, whole societies, planet }\end{array}$ \\
\hline Business status & Mainly use of profits, giving back & $\begin{array}{l}\text { Use of profits, how profits are made, value } \\
\text { creation }\end{array}$ \\
\hline Governance status & Mainly apart from government-led governance & $\begin{array}{l}\text { Partner in multiactor private governance, } \\
\text { entailed in government-led (national and } \\
\text { international) governance regulation }\end{array}$ \\
\hline Organizational status & "Complete organization" & "Integrated partial organization" \\
\hline Modes & Philanthropy, partnerships & $\begin{array}{l}\text { Philanthropy, innovation, self-/mutual } \\
\text { regulation, standards and partnerships, MSIs, } \\
\text { government regulation }\end{array}$ \\
\hline Rationale & $\begin{array}{l}\text { CSR enables use of corporate wealth for social } \\
\text { ends }\end{array}$ & $\begin{array}{l}\text { CSR enables use of corporate wealth for social } \\
\text { ends; CSR enables business to be a vehicle for } \\
\text { responsibility; CSR enables wealth creation }\end{array}$ \\
\hline Institutional direction $^{\alpha}$ & Unidirectional (i.e., explicitization) & $\begin{array}{l}\text { Bidirectional and interactive (i.e., hybridization, } \\
\text { explicitization, implicitization) }\end{array}$ \\
\hline
\end{tabular}

\footnotetext{
" These changes are discussed in the section titled "The Dynamics of CSR."
} 
generally, illustrated by their attention to how profits are made (e.g., use of natural resources, emissions, supply chain employment standards) and wider value creation, for example, for "bottom of the pyramid strategies" (Mason, Chakrabarti, \& Singh, 2017; Prahalad \& Hort, 2002.).

Likewise, the governance status of CSR has shifted radically (Table 1). In part, this is because corporations have taken more responsibility for global governance in, for instance, MSIs (Matten \& Crane, 2005; Scherer \& Palazzo, 2007, 2011). But we also have seen closer entailment of governments in CSR regulation (Knudsen, Moon, \& Slager, 2015; Kourula, Moon, Salles-Djelic, \& Wickert, 2019; McBarnet, 2007) and with corporations and other private regulators in the cocreation of new governance systems (Bernstein \& Cashore, 2007; Knudsen \& Moon, 2017; Scherer, Rasche, Palazzo, \& Spicer, 2016).

International governmental organizations (IGOs) increasingly regulate CSR (Abbot, Genschel, Snidal, \& Zangl, 2015; Ruggie, 2002, 2004). The UN Global Compact (1999) enabled corporations to commit themselves to ten basic principles, mainly derived from international treaties (Rasche, 2009; Rasche \& Waddock, 2014). The UN Sustainable Development Goals (SDGs) have been widely adopted by corporations in the management and communication of their policies. Other examples of IGO interest in CSR include the UN Principles for Responsible Investment, the UN Principles for Responsible Management Education, the OECD Guidelines for Multinational Enterprises, the ASEAN CSR Network, and the numerous regulations and initiatives of the European Union.

There have also been changes in the organizational status of CSR (Table 1). CSR departments are more firmly established in corporations, more integrated, and more closely connected to boardlevel deliberations (Grayson \& Kakabadse, 2013), as are issues of business ethics (Rasche, 2019). Moreover, the organization of CSR within corporations has shifted from "complete" to "partial" organization by corporations (Ahrne \& Brunsson, 2011). Thus, corporations have opened themselves to external actors-not only core stakeholders-in their adoption of CSR standards and their membership in CSR partnerships (Rasche, de Bakker \& Moon, 2013). Such standards and partnerships reflect not only the interests and values of corporations' core stakeholders but also those of competitors; civil society, labor, and professional organizations (e.g., accountants, biologists, health scientists); and regulators at local, national, and international levels.

These changes in the business, governance, and organizational status of CSR are together reflected in the changing modes of CSR (Moon, Murphy, \& Gond, 2017), or how CSR is enacted (Table 1). The most obvious shift here is from the predominance of philanthropy and local partnerships, evident especially in the United States (Maignan \& Ralston, 2002), to national and international cross-sectoral partnerships (Seitanidi \& Crane, 2014), standards (Gilbert, Rasche, \& Waddock, 2011), and MSIs (de Bakker, Rasche, \& Ponte, 2019).

This brings us to the changes in the rationales for CSR (Maignan \& Ralston, 2002; Moon et al., 2017). A long-term assumption about CSR has been that surplus wealth could be deployed for social purposes, associated with paternalism or "noblesse oblige"; stewardship; and philanthropy (i.e., what corporations do with their profits). A clear new rationale is evidenced in the way that corporations increasingly present their business models as vehicles for social change (i.e., how they make their profits; Table 1). This was once associated with niche areas of business that were "born"' with a social mission (e.g., The Body Shop, Ben \& Jerry's, Patagonia), but more mainstream corporations are now integrating CSR into their core business strategy (e.g., Unilever; see Lawrence, Rasche, \& Kenny, 2015). This sense of social mission has often been justified with reference to its business benefits, a rationale renewed in light of the popularization of the concept of "creating shared value" (CSV; Porter \& Kramer, 2011, but see critiques such as Crane, Palazzo, Spence, \& Matten, 2014, and Vallentin \& Spence, 2017). Many corporations have been exploring and communicating precisely that their CSR brings value to society and to their company (i.e., their core stakeholders). This form of rationalization has been illustrated both with respect to cost savings (e.g., from reducing negative omissions or lowering consumption of natural resources) and with respect to benefits such as more secure supply and new markets that CSR-based business models are expected to yield.

Many reinterpretations of CSR's meaning over the last two decades reflect ways of accommodating the changes illustrated in Table l. For example, Porter and Kramer (2011) and Scherer and Palazzo (2007, 2011) both illustrate CSR's internationalization, the expansion of CSR issues to 
societal agendas at large, and the progression of CSR from "use of profits" to "the making of profits." Porter and Kramer do not appear to consider CSR's changing governance status (if anything, they advocate bypassing government), organizational status, and modes, whereas Scherer and Palazzo recognize all three CSR dynomics.

However, in recognizing the changing business status and rationales (Table 1), Porter and Kramer argue that the phenomenon they identify, CSV-a business case for social investments based on a stakeholder model-is different from CSR. As we indicate below, our wider definition of CSR embraces not only CSV but also earlier policies, strategies, and practices reflecting the "business case for CSR" (e.g., Griffin \& Mahon, 1997; Hart, 1995; Hart \& Milstein, 2003). Indeed, this rationale was espoused two centuries ago by Robert Owen, founder of the cooperative movement, who argued that "fair treatment of workers could result in a return equal to 50 percent to 100 percent on money invested" (quoted in Husted, 2015: 127).

Scherer and Palazzo (2007, 2011) do not offer political CSR as something wholly different but, rather, as reflecting distinctive roles for corporations in global governance. We concur that their specific insight into CSR's new global (or, perhaps, more usually "international") governance roles is insightful and important (Crane, Matten, \& Moon, 2008; Matten \& Crane, 2005). Our main concern here is that naming this "political" CSR could lead the reader to overlook long-standing evidence that CSR brings political responsibilities at the local and national levels (Boswell, 1983; Husted, 2015; Moon, 1995; Moon et al., 2017; Moore et al., 1985).

So, our stylized interpretation of CSR then and now has illustrated some of the key questions and debates about CSR's meaning (Table 1). Because of some of the changes we depict, Porter and Kramer (2011) argue for replacing CSR with another concept (creating shared value), and Scherer and Palazzo (2011 in particular) justify delineating a subconcept (political CSR). In our discussion of the meaning of CSR, we indicate why we think neither conceptual move is warranted, notwithstanding the value of the authors' respective insights into key CSR dynamics.

\section{THE MEANING OF CSR}

In reflecting on the 2008 article's contribution to the meaning of CSR, we note that our CSR definition enables inductive analysis of CSR in its comparative and dynamic contexts. We now "backfill" some of our assumptions about CSR and legitimacy in the 2008 article by conceptualizing corporate motivations for legitimacy in the context of relationships between the corporation and, respectively, its core stakeholders, ${ }^{2}$ societies the corporations operate in, and the regulators (public and private) the corporations are subject to. The relationships of corporations with these actors have a different and changing character, depending on institutional context, both in terms of place and time. But it is with these actors in their specific institutional contexts that corporations need legitimacy, and, we argue, CSR provides a means of securing such organizational legitimacy (Deephouse, Bundy, Tost, \& Suchman, 2017; Durand, Hawn, \& Ioannou, 2019).

Depending on the constellation of these actors and their institutional contexts, CSR might reflect compliance with societal norms or regulation (public or private) and be implicit, or it might reflect volition and be explicit. The success of these legitimacy strategies will be reflected in benefits to the corporation if the CSR is regarded positively (Meyer \& Rowan, 1977; Suchman, 1995). Thus, a positive assessment of the corporation's CSR by its core stakeholders (e.g., as contributing to business performance) will be rewarded by further resources vital to business operation (notably, capital, labor, payments, input materials, products and services, and community approval). A positive assessment of the corporation's CSR by societies in which the corporation operates will be reflected in the corporation's benefiting from a general reputation as socially appropriate and thereby trustworthy, and from opportunities to be a social partner (e.g., with civil society organizations). A positive assessment of the corporation's CSR by the regulators as congruent with their expectations will be reflected in favorable status in public procurement markets, access to markets in which private regulators have authority, and opportunities to participate in governance (e.g., public-private partnerships, policy-making

\footnotetext{
${ }^{2}$ We specify the corporation's core stakeholders, recognizing that this introduces some conceptual ambiguity (the significance of which will reflect each reader's preferred theory of the firm!). This is because we would expect corporations, like all organizations, to be motivated by self-interest, but that this would reflect the interests of their core stakeholders-even though these are not usually in perfect harmony (Freeman, Harrison, \& Wicks, 2007).
} 
processes, MSIs). Depending on how the particular balances of implicit and explicit CSR are evaluated by the corporation's core stakeholders and by societal and regulatory actors, the corporation may maintain, extend, or otherwise adjust the institutional character of its CSR (Figure 1).

The following section unfolds this argument and explains the components of and relationships within Figure 1.

\section{The CSR Definition}

Whereas Bowen (1953) began the modern conceptualization of business social responsibility with the individual "businessman" (see also Davis, 1960), which was followed by attention to the individual organization (e.g., Carroll, 1979; Heald, 1970), our 2008 definition also gave attention to the societal context of business responsibility. This focused on the roles of cultural norms and regulatory environments, as well as on actors beyond the core stakeholders, such as civil society and government.

We avoided defining CSR in a way that simply reflected the policies, strategies, and practices of a single context to allow the respective features and applications of CSR from different national business systems (NBSs) to speak for themselves. Thus, we offered a definition of CSR that was sufficiently capacious-or roomy-for inductive reasoning and analysis, particularly for analysis of comparative and changing CSR:

Thus, CSR (and its synonyms) empirically consists of [clearly articulated and communicated $]^{3}$ policies and practices of corporations that reflect business responsibility for some wider societal good. Yet the precise manifestation and direction of the responsibility lie at the discretion of the corporation. (Matten \& Moon, 2008: 405).

In this respect, our definition is therefore consonant with that of Bowen, who also defined CSR openly: "those policies, ... those decisions, or ... those lines of actions which are desirable in terms of the objectives and values of our society" (1953: 6).

Our 2008 article's definition differs from conceptions of CSR that identify different actors to whom businesses are responsible, as in the many

\footnotetext{
${ }^{3}$ On reflection, we would drop this bracketed phrase since it leans too far toward the "explicit" form of CSR. We now prefer the definition without the "clearly articulated and communicated," which then equally applies to the explicit and implicit CSR forms.
}

CSR adoptions of the stakeholder model. For example, Waddock and Bodwell defined CSR as "the way in which a company's operating practices (policies, processes, and procedures) affect its stakeholders and the natural environment" (2004: 25).

Our definition also differs from those that specify CSR according to what it is not. For example, many definitions expressly distinguish CSR from corporate behavior that is shaped by the law and government or by business interest. For example, McWilliams and Siegel defined CSR as "actions that appear to further some social good, beyond the interests of the firm and that which is required by law" (2001: 117, emphasis added).

While other definitions recognize the importance of context, they also bring in specific elements that render the definition less capacious. For example, Aguinis defined CSR as "contextspecific organizational actions and policies that take into account stakeholders' expectations and the triple bottom line of economic, social, and environmental performance" (2011: 855; a definition also adopted by Aguinis \& Glavas, 2012, and Rupp, Williams, \& Aquilera, 2010).

Our definition risks attracting the criticism that it does not serve research specifying variables in advance and, on the basis of their frequency, distribution, and correlations found, enables CSR to be traced, compared, and explained. However, our intention was to enable identification of CSR policies, strategies, and practices reflecting different locational and temporal contexts. Our definition also risks criticism that we do not distinguish "fake" (e.g., window dressing) from "real" CSR (e.g., the authentic embrace of societal values in policies, strategies, and practices). Our approach is designed to capture what corporations present as their CSR behavior. We do note in our underlying theory, however (Figure 1 and see below), that core stakeholders, societies, and regulators will evaluate and make judgments on the legitimacy of a corporation's CSR, which we now turn to.

\section{Underlying Theory: Three Institutional Relationships}

The theoretical underpinning of our approach to CSR is captured in the word "legitimacy," which was core to our 2008 conceptualization of CSR in national and new institutional contexts. Here we 


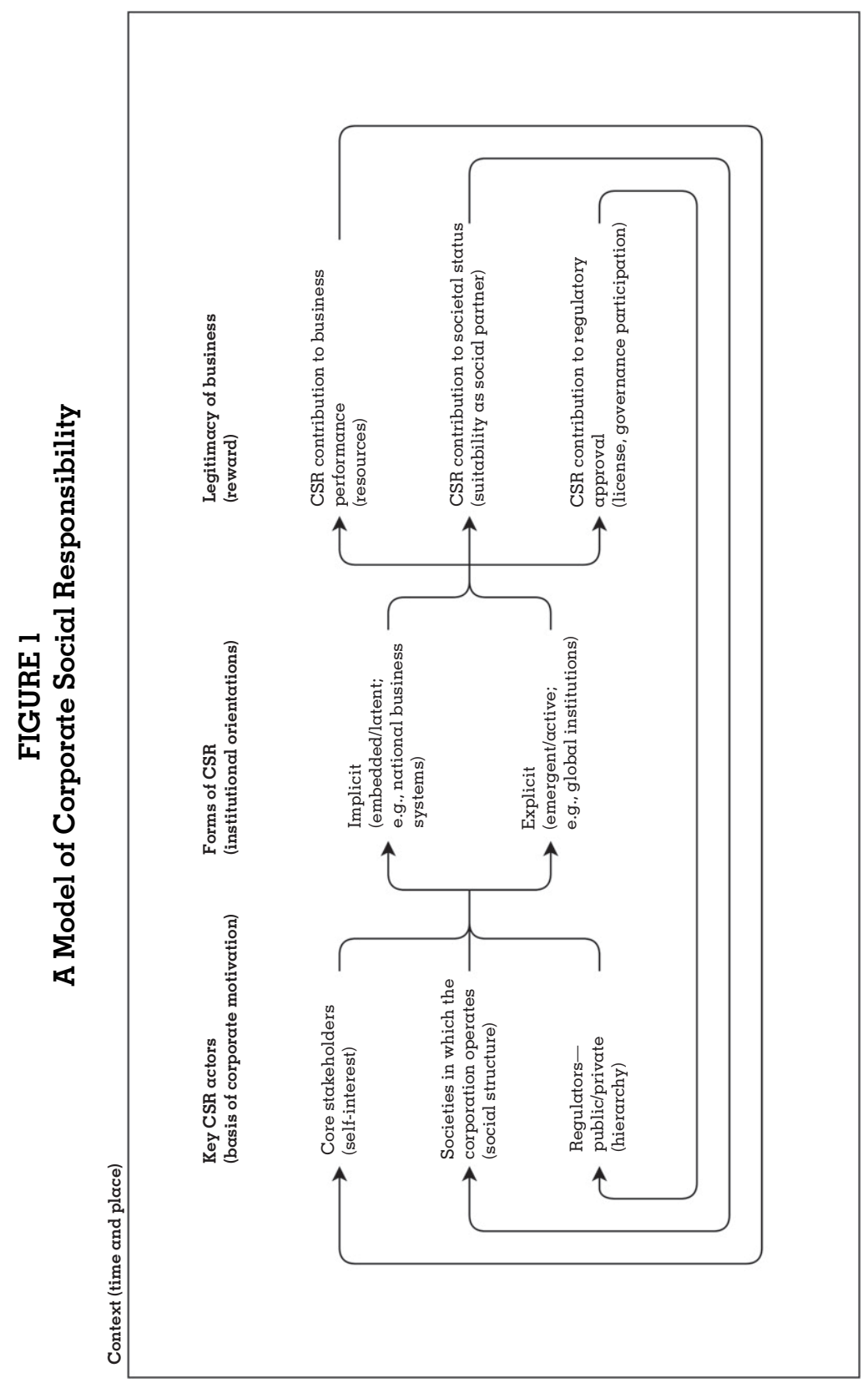


follow Deephouse et al. and define organizational legitimacy as "the perceived appropriateness of an organization to a social system in terms of rules, values, norms and definitions" (2017: 32)

In the context of understanding CSR across time and place, we assume that a corporation's CSR policies, strategies, and practices are developed for the purpose of "gaining, maintaining and repairing" legitimacy (Suchman, 1995: 571). We assume that this is in three distinct institutional relationships that are associated with the key actors corporations depend on for legitimacy and that therefore bring distinctive bases of motivation for corporate policy, strategy, and practice: core stakeholders, society, and regulators. This clearly differs from other perspectives on the question of who confers legitimacy. From a stakeholder perspective (e.g., Freeman, 2009/1984; Mitchell, Agle, \& Wood, 1997), core stakeholders, society, and regulators are all stakeholders of companies. We suggest that from a CSR perspective, these institutions have different types of relationships with the corporation, bring fundamentally different criteria to bear in such evaluations, and potentially bring different resources to the corporation and its CSR. We nonetheless concur with this literature that the task of corporations is to align these relationships (Freeman et al., 2007; Mitchell et al., 1997). The "organizational legitimacy" perspective simply distinguishes "internal" and "external" stakeholders as sources of legitimacy-or legitimacy evaluatorswith anclyses including a wide ronge of societal and regulatory actors (Bitektine \& Haack, 2015; Deephouse et al., 2017; Deephouse \& Suchman, 2008). Our aim is to delineate these legitimacy relationships in the case of CSR.

Drawing from the legitimacy literature, we assume that forms of CSR appropriate to the specific balance of key CSR actors (core stakeholders, societies, and regulators) in their respective context (place and time) will yield legitimacy as a "property" for the corporation (i.e., something that is a valued resource). This, in turn, will reflect interactive "processes" of the construction of CSR and "perceptions" of those legitimacy-giving actors (Suddaby, Bitektine, \& Haack, 2017).

The first institutional relationships for corporations are with their core stakeholders (Freeman, 2009/1984). Notwithstanding the vast literature differentiating stakeholders, their relative priority, and the tensions in balancing these, our point is to distinguish core stakeholders from other actors and to identify what unites them. We suggest that while other actors can affect and are affected by corporations, notwithstanding their distinctive perspectives, shareholders/owners, employees, customers and suppliers, and communities all have an interest in the corporation itself and its market success. Thus, they share an underlying interest in the corporation's existence and prosperity and in bringing resources to that success (i.e., finance, labor, supply, custom; see Barney, 1991). The legitimacy that CSR affords with respect to these institutional relationships is through its contributions to company performance: with its shareholders/owners who derive dividends, with its employees who gain continued employment and remuneration, with customers who derive continued availability of products and services, with suppliers who benefit from continued business, and with communities whose social infrastructure benefits from company operations. This CSR capacity has become a point of increased interest for corporations in light of the rise of attention to it by investors (Friedea, Busch, \& Bassen, 2015; O'Sullivan \& O'Dwyer 2015), consumers (Reisch \& Thøgersen, 2017), and employees (El Akremi, Gond, Swaen, De Roeck, \& Igalens, 2018; Glavas, 2016; Jones, Willness, \& Madey, 2014; Vlachos, Panagopoulos, \& Rapp, 2014).

Turning to the second institutional relationship of corporations, as Polanyi (1957) noted, all markets are embedded in human societies, and, thus, corporations need to secure, maintain, and repair legitimacy in the different "social structures" (Gronovetter, 1985) where they operate. We expect this to require broad conformance with and support for the values espoused or recognized by those societies (Boswell, 1983). This can include tailoring CSR to social expectations whether in nineteenth-century Europe and North America (Djelic \& Etchonchu, 2017; Husted, 2015) or in contemporary United States (Carroll, Lipartito, Post, \& Werhane, 2012; Maignan \& Ralston, 2002) and Asia (Kim \& Moon, 2015). In recent decades, specific elements of societal opinion have been represented-and mediated to corporations-by civil society organizations (den Hond \& de Bakker, 2007; Seitanidi \& Crane, 2014), often accentuated by media and social media involvement (Carroll, 2011; Ihlen, Bartlett, \& May 2011). In some cases this societal interest reflects implicit assumptions about CSR as compliance, and in others it may reflect volition by corporations, whether to gain legitimacy (e.g., entering a new market), maintain 
legitimacy (e.g., particularly in times of threats to the legitimacy of the corporation, the sector, or business more widely), or repair legitimacy (e.g., after a scandal; Pfarrer, DeCelles, Smith, \& Taylor, 2008).

Third, as Polanyi (1957) noted, all markets are created in and maintained by governmental actions, from the specification of the corporate form and the rules of markets to the management of those markets. Governments enjoy a monopoly of legitimate coercion in their jurisdictions, which affords a special authority or "hierarchy" (Granovetter, 1985). These regulators define legal and otherwise codified or authoritative expectations of business responsibility (Kourula et al., 2019). They may thereby reflect, reinforce, and inform societal expectations of business, and they do so through their ability to make and apply standards and rules in their respective jurisdictions (Knudsen et al., 2015) and, in some cases, beyond their borders (Knudsen \& Moon, 2017). This means that to secure legitimacy with these regulators, corporations, at the minimum, need to conform with their rules, but this can extend to enriching the objectives of regulators (McBarnet, 2007; Moon, 2002). In this way, corporations acquire and maintain their legal status, freedom from litigation, and a favorable standing with respect to public procurement and wider regulatory decisions.

But regulation is no longer the sole preserve of governments. The emergence of "new governance" (Moon, 2002; Pierre, 2000) over the last three decades or so has brought to the fore a myriad of nongovernmental regulators of corporations, be it through nonstate market governance (Cashore, 2002), standards organizations (Gilbert et al., 2011), or intermediary institutions (Brès, Mena, \& Salles-Djelic, 2019). These have become an equally important source of legitimacy for many corporations (Scherer \& Palazzo, 2007). One common characteristic of the new governance developments is their international character-especially in the form of MSIs (de Bakker et al., 2019), which tend to combine multiple corporations and civil society organizations. These new regulators therefore bear some hallmarks of the legitimacy relationship associated with governments but in the context of perceived new imperatives for legitimacy across borders (Haack, Pfarrer, \& Scherer, 2014; Kostova, Roth, \& Dacin, 2008; Kostova \& Zaheer, 1999; Scherer, Palazzo, \& Seidl, 2013).
A few points of clarification are warranted here. First, the order of the relationships presented is not intended to convey any necessary prioritization for corporations. We see the balance and nature of the prioritizations as entirely contextual. Second, the differentiation of the relationships is not to suggest that they are independent of one another. On the contrary, they are mutually shaping (Granovetter, 1985). Corporations can shape societal values (through the effects of their products and services; e.g., Whelan, 2017) and regulatory policy (through lobbying; e.g., Anastasiadis, 2014). Societies can inform corporate values (through social regulation; e.g., Boswell, 1983) and government priorities (the essentials of modern democratic theory; e.g., Dahl, 1956). Governments shape the very essence of corporations and their relationships with core stakeholders (Avi-Yonah, 2005). Third, corporations' valuation of these different relationships can change. For example, the U.S. Business Roundtable released a new "Statement on the Purpose of a Corporation" signed by 181 CEOs (see https:// opportunity.businessroundtable.org/wp-content/ uploads/2019/08/BRT-Statement-on-the-Purposeof-a-Corporation-with-Signatures.pdf), superseding previous statements that had endorsed "shareholder primacy." It was described as promoting "an economy that serves all Americans," for "shared prosperity and sustainability for both business and society" and for "our country" (Business Roundtable, 2019).

To illustrate the significance of this underlying theory of institutional relationships, it is instructive to note that notwithstanding their other differences, the authors of CSV (Porter \& Kramer, 2011) and political CSR (Scherer \& Palazzo, 2007, $2011^{4}$ ) share the view that corporations need to secure greater social legitimacy. This resonates with the centrality of this legitimacy relationship in our underlying model of CSR (Figure 1). It should also be noted, though, that for Porter and Kramer (2011), this primarily represents on opportunity for increasing legitimacy with core stakeholders through greater profits, whereas for Scherer and Palazzo (2011), societal legitimacy represents something of an alternative orientation for corporate success to that of maximizing profits.

\footnotetext{
${ }^{4}$ We focus on Scherer and Palazzo $(2007,2011)$ and not the more recent Scherer, Rasche, Palazzo, and Spicer (2016), since the former present a more distinctive analysis of CSR.
} 
With respect to legitimacy with regulators, however, these authors' perspectives take rather different turns. Porter and Kramer (2011) discount this relationship, seeing relationships with core stakeholders and with society as paramount and regarding corporations as offering an alternative source of problem-solving capacity both to governments and to NGOs. Scherer and Palazzo $(2007,2011)$ locate their articles in the context of what appear to be government-free spaces in which MNCs operate and which they also "fill," in collaboration with civil society organizations through MSIs. While recognizing the new contexts that CSR agendas bring for Western MNCs operating internationally, and that new collaborative institutions are indeed orising, we suggest that both views underestimate the imperatives for legitimacy relationships with governmental regulators in home and host countries (as noted in Scherer et al., 2016).

\section{Implicit and Explicit CSR}

Thus, corporations' legitimacy-seeking CSR policies, strategies, and practices reflect three institutional relationships. But the nature and balance of these institutional relationships can vary, often profoundly, according to their wider contexts and will therefore yield different configurations of implicit and explicit CSR.

In our 2008 article we first grounded this aspect of our analysis in the concept of NBSs (Whitley, 1997; see also Whitley, 1992, 1999, 2002a,b) $)^{5}$ to indicate that there are historically grounded national institutions that inform CSR. In these contexts, the expectations of CSR are embedded in and focused on companies in general (and on wider institutions), yielding implicit CSR. Our 2008 article illustrated this in the postwar European context, where the power of corporations and their core stakeholders was moderated by societal and governmental institutions. Other expectations of corporate responsibility are more overt and focused not only on business in general but also on individual corporations, yielding explicit CSR. The 2008 article illustrated this, first, in the U.S. NBSs, where corporations' power is more

\footnotetext{
${ }^{5}$ Others have deployed similar frameworks to distinguish different institutional contexts for CSR, such as Varieties of Capitalism (Hall \& Soskice, 2001, as deployed for CSR analysis by Jackson \& Bartosch, 2016; Jackson, Brammer, \& Matten, 2012; Kang \& Moon, 2012). See also Witt and Redding's (2013) variant of Asian business systems (which captures the institutional significance of subnational business systems).
}

accepted by society and less tempered by government than in the late-twentieth-century Western European context. In the United States, corporations take express and distinctive responsibility for issues relating to some stakeholders-notably, employees, consumers, and community members.

However, in the context of institutional changes emerging with globalization, our 2008 article drew attention to European corporations' adoption of more explicit forms of CSR. We grounded our analysis in the new institutionalism literature, which identified the emergence of homogeneous institutions that operate across national boundaries (i.e., through globalization) and their increasing significance in the respective organizational fields of corporations. These institutions shape the behavior of corporations through "coercive isomorphisms, mimetic processes and normative pressures" (DiMaggio \& Powell, 1983: 147) and therefore deliver legitimacy to those corporations in new global spheres. Our 2008 article applied this fromework to explain the increased adoption of explicit CSR policies, strategies, and practices by European MNCs. The article suggested that institutions embedded in NBSs and those in the organizational fields of corporations will shape corporate strategies for legitimacy, producing different and dynamic configurations of implicit and explicit CSR (Matten \& Moon, 2008: 413, Figure 2).

Our original article described explicit CSR as "corporate policies that assume and articulate responsibility for some societal interest" and implicit CSR as "corporations' role within the wider formal and informal institutions" (Matten \& Moon, 2008: 409). This distinction rested on

1. whether a corporation undertakes and expresses CSR alone (explicit) or as part of an institutional complex (implicit),

2. whether this CSR is presented in terms of the corporation voluntarily undertaking responsible activities (explicit) or adopted by the corporation to reflect wider values and regulations (implicit), and

3. whether the CSR motivations are primarily derived from core stakeholders (explicit) or from a wider and more institutionalized set of actors (implicit; Matten \& Moon, 2008: 410, Table 1).

We presented the differences between the two manifestations of CSR in Table 1 of the 2008 article, ${ }^{6}$ reproduced here as Table 2.

\footnotetext{
${ }^{6}$ We also presented this in Figure 1 in the 2008 article, which is not replicated here.
} 
TABLE 2

Explicit and Implicit CSR Compared

\begin{tabular}{lc}
\hline Explicit CSR & Implicit CSR \\
\hline $\begin{array}{l}\text { Describes corporate activities that assume responsibility } \\
\text { for the interests of society }\end{array}$ & $\begin{array}{c}\text { Describes corporations' role within the wider format and } \\
\text { informal institutions for society's interests and concern } \\
\text { Consists of voluntary corporate policies, programs, and } \\
\text { strategies }\end{array}$ \\
$\begin{array}{c}\text { Incentives and opportunities are motivated by the } \\
\text { codified and mandatory) requirements for corporations } \\
\text { perceived expectations of different stakeholders of the } \\
\text { corporation }\end{array}$ & $\begin{array}{c}\text { Motivated by the societal consensus on the legitimate } \\
\text { expectations of the roles and contributions of all major } \\
\text { groups in society, including corporations }\end{array}$ \\
\hline
\end{tabular}

Source: Matten and Moon (2008: 410).

It has sometimes been assumed that we concluded that the U.S. NBSs had no implicit CSR and that the European ones had no explicit CSR. Certainly, we had envisaged this as a mainly inverse relationship: the more implicit the CSR of on NBS, the less attention corporations would need to give to explicit CSR, and vice versa. Nevertheless, we did not present implicit and explicit CSR as mutually exclusive. Rather, we saw them as ideal CSR types and assumed that both feature in national systems and in companies. We cited Pasquero (2004) to signal how U.S. CSR is embedded "in U.S. institutions and culture, particularly in the traditions of individualism, democratic pluralism, moralism, and utilitarianism" (Matten \& Moon 2008: 409). Indeed, Figure 1 in our 2008 article does not present a pure inverse correlation of implicit and explicit CSR; rather, it is designed to indicate that we would expect a modicum of implicit and explicit CSR in all economic systems and all corporations. However, we argue below (in the section titled "The Dynamics of CSR") that the implicit and explicit forms of CSR are more interactive than we had originally appreciated.

\section{A Framework of CSR}

From our reflections on and development of the 2008 article, it has become evident that rather than just providing an alternative to or an extension of extant CSR theory, our fromework exposes the general nature of CSR. It combines

1. the expectations of corporations' core stakeholders, societies, and regulators that corporate legitimacy would be contingent on, with

2. the specific contexts of corporations' operations (e.g., local, national, international, cultural, industry, value chain) in which they use CSR to secure, maintain, or increase legitimacy, with
3. the resultant forms of CSR, whether implicit (particularly reflecting societal and regulatory expectations of business-and other institutions - in general) or explicit (particularly reflecting core stakeholders' expectations of corporations in particular).

Circumstances of change (e.g., globalization for our 2008 article) unsettle the institutional orientation of CSR, provoke new legitimacy strategies, and bring new configurations of implicit and explicit CSR. But, as noted, there have been subsequent changes in CSR that we had not anticipated, whose implications for our implicit/explicit fromework we turn to now.

\section{THE DYNAMICS OF CSR}

As indicated in our interpretation of CSR then and now (above), CSR is dynamic. And this is not a new observation: CSR has long been described as "a moving target" (Christensen, Morsing, \& Thyssen, 2013: 372). Our purpose here is to reflect on some of the dynamics of CSR as depicted in Table 1 in light of the implicit-explicit CSR conceptualization presented in the 2008 article and the framework of CSR explicated above (Figure 1). First, we consider CSR change through the evidence of hybridity of implicit and explicit CSR; second, we explore the twin processes underlying this hybridization-namely, explicitization and implicitization. We present these terms in the bottom row of Table land attempt to relate them to the other changes in CSR characteristics we have identified.

\section{Hybridization of Explicit and Implicit CSR}

We had not anticipated the extent and nature of hybridity in North America and Europe, let alone 
more widely. Recent research has found that these processes are, to quote Hiss, not "radical, frictionless or uni-directional" but "unexpected, paradoxical and dialectical" (2009: 445). Moreover, the Western European trajectories from implicit to explicit CSR are not synchronized with one onother, as a U.K. and German comparison of trajectories reveals (Silberhorn \& Warren, 2007). While Europe has witnessed a move to greater explicit CSR, this has reflected not only the corporate volitions and strategies that we associate with explicit CSR in the United States but also those we associate with key roles played by the private and public regulators that we have identified with implicit CSR (Matten \& Moon, 2008: 416-417). Thus, European explicit CSR policies and practices emerged with the involvement of governments (Albareda, Lozano, Tencati, Midttun, \& Perrini, 2008; Knudsen et al., 2015; Steurer, 2010), industry associations (Kinderman, 2012), nongovernmental organizations (den Hond \& de Bakker, 2007), and labor organizations (Preuss, Haunschild, \& Matten, 2006). In other words, the societal and regulatory actors that had institutionalized European implicit CSR adapted to change in their business environments and were part of the reinstitutionalization of CSR in more explicit forms.

Numerous evaluative issues have arisen. Some authors have pointed to the advantages that Scandinavian companies have in conforming to new explicit expectations by virtue of their strong implicit CSR legacies (e.g., Gjølberg, 2009). Thus, implicit CSR provided experience of some of the practices more associated with explicit CSR. Other authors have pointed to the tensions that CSR managers face both in complying with the new explicit CSR (which stresses communication strategies) and in abiding with the old implicit CSR (in which communication was not a feature; Schmeltz, 2014; see also Carson, Hagen, \& Sethi, 2015, and Kujala, Rehbein, Toikka, \& Enroth, 2013). It has been conjectured that overzealous CSR communication would be seen as immodest in the traditional Scandinavian implicit model (Strand, Freeman, \& Hockerts, 2015). This tension can be exacerbated given the roles of government in driving explicit CSR in such countries (Carson et al., 2015; Midttun, Gjølberg, Kourula, Sweet, \& Vallentin, 2015).

A number of studies have focused on the processes by which business organizations, companies, and managers alike are grappling with balancing long-standing implicit assumptions (e.g., about community obligations) with new CSR systems encouraging explicit CSR. Horris, Kim, Amaeshi, and Suh (2013) illustrated how tensions have emerged for South Korean CSR managers seeking both to conform to long-standing implicit expectations and to new regulatory demands for more explicit CSR conformance, and they noted how the new implicit/explicit balances of CSR differ among South Korean industrial sectors. Reddy and Hamann (2018) focused particularly on the disparate roles of less developed SubSaharan states in encouraging both implicit and explicit forms of CSR.

The challenge of analyzing and understanding CSR in these non-European country contexts is that the implicit element is often more strongly embedded in informal institutions, religious traditions, and customs, rather than in formal systems of tripartism, neocorporatism, and law more reminiscent of Europe. Moreover, these contexts bring very different forms of exposure to globalization also reflecting their different business systems (see Witt \& Redding, 2013), as well as commercial considerations reflecting their place in global value chains. More generally, research in this area stresses the roles of implicit institutional factors in shaping the way explicit CSR is adopted (Jamali \& Karam, 2018; Jamali, Osuji, \& Onyeka, in press).

We now turn to examining two processes integral to the hybridization of implicit CSR and explicit CSR: explicitization and implicitization.

\section{Explicitization}

In the context of the general rise of explicit CSR in countries that were more strongly associated with an implicit CSR approach, we find that corporations not only adopt more explicit CSR through innovation but also redefine traditional implicit CSR expectations in explicit CSR terms and, thus, develop more explicit policies, strategies, and practices. If one sifts through nonfinancial reports or analyzes the explicit CSR practices of corporations in many West European countries, one will find numerous social performance indicators related to environmental protection, health care contributions, or workers' protection and participation, for example, which are long-standing practices of implicit CSR of corporations in those countries. Many of those are MNCs with a strong export business and have made explicit CSR $a$ standard mimetic practice in 
anticipation of evaluation by societies and regulators in host country markets (Gjølberg, 2009).

Indian corporations make explicit CSR policies, strategies, and practices (including communication) about what they have traditionally done as part of the implicit expectations of their institutional environment. For example, many had long provided welfare services to local populations motivated by traditional, nationalistic, and often religiously motivated informal institutions. Having become more exposed to global organizational fields, these companies are reframing such implicit practices in terms of explicit CSR. The Tata organization, which for one and $\alpha$ half centuries practiced implicit CSR (Elankumaran, Seal, \& Hashmi, 2005), now operates a sophisticated system of what it calls sustainability management as a form of explicit CSR (Ararat, Colpan, \& Matten, 2018; Tata \& Matten, 2016).

This pattern is also evident in developing economies. In Africa, while informal institutions such as Ubuntu and other entrenched forms of stakeholder engagement (Rossouw, 2005) have been long-standing, there is "translation" of these systems and practices into various forms of explicit CSR. Jamali and Karam have revealed the significance for contemporary explicit CSR in developing countries of implicit institutions (e.g., "values, customs, attitudes . . . influence of ideology and related institutions ... patriarchal forms of business management" [2018: 37]), which are reflected in organizational practices (e.g., "duty ... seeking political legitimacy ... meeting localized expectations of power-holders ... meeting local populations' expectations" [2018: 39]) and in individual attitudes (e.g., "values . . . religious orientations . . . attitudes to cultural patterns" [2018: 40]).

Similar dynamics can be observed even in areas that had been assumed to be core implicit responsibilities, such as corporate taxation (Moon \& Vallentin, 2019). Some Western corporations (e.g., Ørsted \& Mærsk in Denmark, Starbucks in the United Kingdom, Google and Facebook in the United States) have adopted explicit CSR policies for responsible corporate taxation (after having been silent on the matter for decades). Some have elected to take a collective explicit approach to responsible corporate taxation. The B Team (an association of business and civil society leaders), which aspires to move "beyond CSR as a vehicle for profit to doing business for social and planetary wellbeing," launched its responsible tax principles (B Team, 2018) regarding tax management, relationships, and reporting. This includes reference to board oversight, compliance with national law where business is done, and reflecting business structures created only for commercial reasons - all of which were implicit expectations in the respective NBSs (see also https://www.csreurope. org/governance-and-accountability/tax-project-taxtransparency-responsible-tox-behaviour).

Thus, explicitization consists largely of the inclusion and transformation of habitual practices that had been unheralded by the respective corporations within CSR and wider corporate policy and strategy (reflecting their ertswhile implicit status). To be clear, we are not arguing that all contemporary explicit CSR emanates from explicitization. That would be to ignore the myriad forms of innovation and new CSR spheres and practices that are clearly also emerging. Our point is simply that in the midst of the tide of explicit CSR adoption and development, there is a powerful current of explicitization of what was once only implicit.

We suggest that these developments can be traced back to our three legitimacy relationships and their interactions and configurations. First, there is a much more active societal issue focus on CSR, reflected in normative pressure on corporations (Table 1). This is brought by civil society activists, social media, and public opinion polls that focus on business responsibility and irresponsibility. Societies and their representatives often ask for "proof" of CSR, and, thus, explicit commitments and accounts of behavior are an obvious means for corporations to respond to this pressure. This suggests that much of CSR internationally (Table 1) does not simply reflect adoption of U.S. CSR agendas, or those of inwardinvesting MNCs. It also represents a renewed pursuit of long-standing societal norms now reflected in the adoption of explicit CSR policies, strategies, and practices.

Second, as governments now provide regulation for reporting (see below), they create further isomorphic pressures for corporations to comply with and, in so doing, reinforce the pressures for explicitization through their CSR reports. Likewise, the changing governance and organizational status and modes of CSR (Table 1) bring new regulators, which also contribute isomorphic pressure for more explicit CSR. Many of the new "mesolevel" institutions between societies and 
markets, such as the MSIs and the new business associations and standards organizations, also require demonstrations of CSR on the part of their members or those they seek to regulate. They require evidence that corporations do more than simply sign up to principles and that the corporations evidence how they reflect and enact these principles in the form of policies, strategies, and practices. Likewise, there are new IGO sources of isomorphic, mimetic, and normative pressures that encourage explicitization in the way corporations enact their CSR (e.g., the UN Global Compact Ten Principles).

Third, reflecting their own respective interest in CSR's changing issue focus, business status, modes, and rationales, core corporate stakeholders also bring pressure for explicitization of long-standing implicit norms and regulations. This is in the form of demands for reassurance about such activities as responsible investment, responsible sourcing, and responsible employment practices, for which CSR regulators, old and new, now provide ready definitions and measures.

But hybridization does not only consist of the explicitization of the implicit. There is also implicitization of the explicit, which we turn to now. Table 3 summarizes the concepts of explicitization and implicitization.

\section{Implicitization}

As indicated in Table 3, implicitization refers to processes by which formal and informal institutions integrate into their norms and rules expectations and obligations for corporations derived from explicit CSR policies, strategies, and practices. This is especially evident in the roles of national government and the "new CSR regulators" involving civil society and IGOs. There are also signs that this may also be taking place in wider societal norms. Although it is probably too early to conclude that these formerly explicit CSR practices are now firmly "business as usual," what we detail below is, at least, suggestive that voluntary strategies are becoming more a matter of regular compliance. And this has historic resonance, given ways in which early-twentiethcentury Europe and North America labor, welfare, and environmental norms and rules often reflected the examples of nineteenth-century CSR pioneers (Husted, 2015).

Implicitization is most evident in the wave of new national governmental regulation for CSR. All European governments have developed regulation for CSR across the range of policy areas, from social and environmental to economic and international, and with a variety of regulatory tools, from endorsement to mandate (Gond, Kang, \& Moon, 2011; Knudsen et al., 2015). In many of these cases the governments have simply complemented corporate trends with their own policy frameworks. Nonfinancial reporting-hitherto a quintessential explicit CSR activity quite removed from societal norms and regulatory frameworks - is now a regulatory requirement of most European and North American, and many Asian, governments, either through general regulation or through stock exchange governance requirements (KPMG, 2017). The Danish approach reflects a gradual strengthening of CSR reporting regulation. Initially, soft regulation targeted only a very narrow class of corporations, enabling them to use very wide discretion-even to avoid

TABLE 3

Explicitization and Implicitization of CSR Compared

\begin{tabular}{|c|c|}
\hline Explicitization of CSR & Implicitization of CSR \\
\hline $\begin{array}{l}\text { Describes explicit adoption by corporations of responsibility } \\
\text { for society's interests and concerns that had been regulated } \\
\text { by wider formal and informal institutions }\end{array}$ & $\begin{array}{l}\text { Describes adoption by wider formal and informal institutions } \\
\text { of CSR policies that had been deployed explicitly by } \\
\text { corporations }\end{array}$ \\
\hline $\begin{array}{l}\text { Consists of voluntary corporate policies, strategies, and } \\
\text { practices whose underlying norms corporations had } \\
\text { previously conformed with implicitly }\end{array}$ & $\begin{array}{l}\text { Consists of new/reinvigorated values, norms, and rules for } \\
\text { corporations that are informed by policies, strategies, and } \\
\text { practices of explicit CSR }\end{array}$ \\
\hline $\begin{array}{l}\text { Incentives and opportunities are motivated by the perceived } \\
\text { expectations of stakeholders, society, and regulators }\end{array}$ & $\begin{array}{l}\text { Requirements for compliance are motivated by integration of } \\
\text { expectations of CSR into a new consensus of legitimate } \\
\text { expectations of all major groups in society, including } \\
\text { corporations }\end{array}$ \\
\hline
\end{tabular}


reporting if they explained that they had no CSR. This has been followed by increased compliance requirements (e.g., the increased specification of issues corporations must report on) and a spread of the types of companies the regulations apply to (Knudsen \& Moon, 2017; Vallentin, 2015).

Other areas of adaptation of explicit CSR practices into regulatory norms include the new U.S. legal charter for the Benefit Corporation (B Corp), which provides implicit regulatory underpinning for companies to specify their social and financial objectives to their core stakeholders, the public at large, and regulators (Strine, 2014). This combines an implicit form for CSR with explicit content. Other examples of regulation for what had been explicit CSR issues include U.K., French, and Dutch requirements for due diligence in international supply chains to avert child labor and slavery; the adoption by the Norwegian government of voluntary ethical trading codes for public purchasing; the Indian government's CSR tax (Mitra \& Chatterjee, 2019); the Chinese government's numerous CSR regulations, particularly on the export sector (Hofman \& Moon with Wu, 2017); and, somewhat more indirectly, the use of legality verification to effectively make voluntary agreements binding (e.g., in forestry governance; Cashore \& Stone, 2012).

There is also evidence that some industry bodies, sector associations, and professional organizations are seeking to build formerly explicit CSR practices into the normal business behavior of their members. In some countries this trend is accelerated by trade unions and works councils that have become rather active in translating and importing explicit CSR proctices into the existing frameworks of workers' participation (Preuss et al., 2006). One of the main implications of this development is that explicit CSR has, paradoxically, become more governed by rules, whether private, public, or hybrid and whether in the form of agreements, codes, or soft law regulations. Parts of many industries now are governed by such "voluntary" rules as in commodities, be it agriculture or mining, apparel, ICT, and finance, whereby formerly explicit CSR policies take the form of implicit CSR for the sector, governed by those newly created partnerships, associations, and MSIs.

It is also worth noting evidence that evaluation of corporations' CSR is becoming a more common societal practice. CSR now features in many opinion polls, particularly since the Millennium
Poll on Corporate Social Responsibility (Environics International, 1999). Moreover, new social movements, often through the new media, have succeeded in popularizing key CSR issues by mobilizing public responses to the 2008 finoncial crisis, the release of the Panama Papers, and, more generally, the impacts of corporations on climate change. Concepts such as fair trade, organic forming, and sustainable timber and fish-once the exclusive lexicon of the cognoscenti-have become popularized on the high streets through labeling on products of major bronds.

Overall, implicitization could be regarded as a process of "normalization" of CSR agendas and practices in different business systems. Clearly, its effects remain partial, since many of those attempts to institutionalize CSR in underlying norms and rules are still largely linked to institutions and agreements that only have a limited regional, sectoral, functional, value chain, or market reach. What is surely true is that regulators, private and public, are incorporating formerly explicit CSR agendas to define more generalized expectations of business.

\section{DISCUSSION}

\section{Contributions}

The focus of this article is on the meaning and dynamics of CSR. It contributes by deepening and extending our earlier analysis of implicit and explicit CSR (Matten \& Moon, 2008). Of course, CSR meaning and dynamics are mutually entailed as in any essentially contested concept. This is because any change might be considered, by some, to be consistent with the prior agreed meaning of the concept, while for others that same phenomenon might be considered not as change but as difference, because they would consider that some aspect of that change was inconsistent with the prior agreed meaning (Gallie, 1955-1956). Thus, our first contribution has been to justify our earlier article's capacious definition of CSR because it is not overly constrained by any particular temporal or spatial context, and it is relatively independent of particular issue agendas, modes of responsibility, or rationalizations.

Second, this article has deepened the 2008 article's conceptualization of CSR context by moving from the specifics of NBSs and focusing on three key legitimacy relationships for CSR, 
between corporations and core stakeholders, societies at large, and regulators. We propose these three types of relationship as "legitimacy variables" that will feature one way or another in any business system context and will inform configurations of implicit and explicit CSR.

Third, whereas in our earlier article we drew on notions of legitimacy derived from theories of NBSs and neoinstitutionalism, in this essay we have drawn on the organizational legitimacy literature to strengthen the conceptualization of these corporate relationships and of the legitimacy they derive from CSR. Taken together, these contributions enable a model for CSR that differentiates expectations about business responsibility in their context and that links these with the forms of implicit or explicit CSR that corporations reflect or generate, and with the respective forms of legitimacy these CSR configurations yield and their associated rewards (Figure 1).

This article also extends our 2008 article's analysis of CSR dynamics by building on insights from other researchers concerning the hybridization of explicit and implicit CSR to conceptualize explicitization and implicitization of CSR. CSR explicitization is the adoption for explicit CSR purposes of underlying societal norms and regulators' policies that had hitherto governed the wider institutions in which corporations participate (i.e., implicit CSR). CSR implicitization reflects the adoption of policies, strategies, and practices associated with explicit CSR into wider informal and formal institutions by which corporations-and other actors-are regulated.

When introducing these concepts, we did not venture into normative judgments. One can imagine different views as to whether explicitization and implicitization are to be welcomed, in part reflecting their context. With respect to explicitization, it might be considered welcome - and even overdue - that corporations take societal and regulatory expectations to heart. Conversely, one might also object that if the emphasis here is purely on corporate rhetoric (which, to be clear, we do not assume), then this would merely smack of window dressing (Friedman, 1970) or greenwash (Bowen \& AragonCorrea, 2014). From another perspective, one might fear that excessive mimicking of implicit norms for explicitization might stifle CSR innovation. Our argument is not that all explicit CSR is the result of explicitization of the formerly implicit. We recognize that current explicit CSR-particularly in relation to sustainability agendas-reflects corporations' volition for innovation quite apart from their adoption of the currency of implicit CSR, which we distinguish as explitization.

The trend toward the implicitization of CSR may bring concerns that some corporations will seek to avoid its effects. For example, the U.S. SarbanesOxley Act (2002) and Dodd-Frank Act (2010) have both been associated with de-listings from the U.S. stock exchanges and with the growth in private equity and hedge fund activity motivated by a desire to avoid the respective regulations. More broadly, there is a fear that the tightening of regulations targeting bribery, foreign corruption, tax evasion, unfair or abusive labor practices, and other socially irresponsible business practices has led some corporations to contract out activities that might otherwise make them susceptible to the wrath of the law and, thus, enabling them to maintain their legitimacy through CSR. It has also been suggested that some Indian companies are reluctant to consider their responsibilities for human rights in their supply chains because they have met their CSR obligations through payment of the Indian CSR tax (Agarwal, 2018; Srinivasan \& Parvathy, in press).

\section{Limitations and Further Research}

We can identify several limitations to our analysis. First, we describe our opening depiction of CSR then and now (Table l) as a stylized interpretation for the purpose of introducing CSR and the significance of its dynamics. Because our 2008 and present analyses are institutional and stress the significance of context, we are the first to note that Table 1 is hardly an exhaustive or comprehensive account of CSR!

Second, concerning our definition of CSR, we have already noted that this brings some methodological and evaluative challenges. It might be observed that by deploying an overly capacious CSR definition, we are in the end "comparing apples with tables," or that "if CSR is everything maybe it is nothing" (to borrow from Wildavsky, 1973: 127). To reiterate, we advocate analysis that differentiates forms of CSR, obviously between its implicit and explicit forms but also between its "issues, modes and rationales" (Moon et al., 2017: 32), for example. Concerning the question about how we can be sure that corporate policies, strategies, and policies meet our CSR definition "for some wider societal good" (Matten \& Moon, 
2008: 405), we note that while our framework does not include further normative criteria, it assumes that CSR claims of companies will be evaluated by core stakeholders, societies, and regulators in the process of legitimization or otherwise.

Third, while evidence of explicitization of CSR is available, it is more difficult to be conclusive about implicitization. The fact that societal and regulatory actors are advancing norms and regulations to govern CSR does not automatically mean that implicitization has taken place. This is merely a first step, and the answer to the question of whether these initiatives have led to some normalization of the new CSR expectations will need to echo Zhou Enlai's (famously misattributed) verdict on the significance of the French Revolution: "It is too soon to say."

Other limitations to our article bring opportunities for further research. The relationships of the processes of explicitization and implicitization (what we call institutional direction in Table 1) to the other CSR characteristics that we use to compare CSR then and now offer an avenue for closer investigation. Research can examine if and how each process is associated with CSR's characteristics: context, issue focus, business status, governance status, organizational status, modes, and rationale.

There is plenty of scope for further research to probe and elaborate on our underlying theory with reference to three types of legitimacy relationships. Questions here might include the balance and nature of relationships among these in informing explicit and implicit forms of CSR, particularly through explicitization and implicitization, and their implications for CSR policies, strategies, and practices in different contexts.

We suggest that there are particularly rich opportunities for exploring the processes of explicitization and implicitization in "developing" or "emerging" business systems. In the 2008 article framework, the concept of implicit CSR was mainly based on formal Western institutions. But in many parts of the world, large sections of the economy are regulated by nonformal institutions, with or without formal ones (Kim \& Moon, 2015). These circumstances are sometimes described as "institutional voids," but often it is simply that the institutions are different from those in Western business systems (Jamali \& Karam, 2018; Jamali et al., in press). The more important questions concern the nature, explanation, and evaluation of the explicit and implicit forms of CSR in such contexts, and of their dynamics, including through explicitization and implicitization.

Another limitation to our analysis is that we do not attend to "the politics" of explicitization and implicitization. Historically, key CSR watersheds have been explained by issues of power and interest, whether of corporations trying to avert regulation (Kaplan, 2014), of governments trying to engage CSR to secure their own agendas (Kinderman, 2012; Moon, 2005), or of political parties bringing distinctive policy approaches to CSR within the same country (Vallentin, 2015). In international politics we have seen the rise of corporate power in governance of CSR and sustainability (Ponte, 2019). Moreover, we have two major political watersheds in prospect that might reframe CSR as currently understood. First, there is a revival of nationalism on all continents, bringing the potential for tempering or even reversing globalization toward a more patchwork world in which national and subnational contexts resume their erstwhile significance for CSR (Witt, 2019). Second, the external dynamics for CSR in Africa are becoming less a matter of colonial legacies and Western-initiated investment and supply chains and more a reflection of BRIC investments reflecting close governmental involvement, particularly from China (Taylor, 2014). Hence, research could address questions concerning how and why political power is reflected in emerging forms of explicitization and implicitization.

Likewise, this essay does not engage with organizational-level questions, also critical in periods of CSR adaptation. Thus, research could investigate how corporations resolve organizational challenges of their CSR explicitization strategy (Vigneau, Humphreys, \& Moon, 2015) or how they integrate their explicitization approaches across their international subsidiaries (Gutierrez Huerter O, Moon, Gold, \& Chapple, in press). Such questions about how corporations organize for explicitization can be particularly interesting in view of the trend of increasing partial organization of CSR reflecting the roles of civil society and even regulatory actors in corporate policies, strategies, and practices (Rasche et al., 2013).

We have two final reflections. First, revisiting an article confirms that we are all too human, and there were things we would rather have done differently. Second, events are a great test of ideas, and in the period that we were devising our 
implicit-explicit CSR framework, we did not envisage the developments captured in our then and now and hybridization analyses. This raises the question about the meaning and dynamics of CSR in 2028 ... so we look forward to another decade of debate about and analysis of CSR.

\section{REFERENCES}

Abbot, K. W., Genschel, P., Snidal, D., \& Zangl, B. 2015. International organizations as orchestrators. Cambridge: Cambridge University Press.

Agarwal, N. 2018. Measuring business responsibility disclosures of Indian companies: A data-driven approach to influence action. Business and Human Rights Journal, 3: 123-129.

Aguinis, H. 201l. Organizational responsibility: Doing good and doing well. In S. Zedeck (Ed.), APA handbook of industrial and organizational psychology, vol. 3: 855-879. Washington, DC: American Psychological Association.

Aguinis, H., \& Glavas, A. 2012. What we know and don't know about corporate social responsibility: A review and research agenda. Journal of Management, 38: 932-968.

Ahrne, G., \& Brunsson, N. 2011. Organization outside organizations: The significance of partial organization. Organization, 18: 83-104.

Albareda, L., Lozano, J. M., Tencati, A., Midttun, A., \& Perrini, F. 2008. The changing role of governments in corporate social responsibility: Drivers and responses. Business Ethics: A European Review, 17: 347-363.

Anastasiadis, S. 2014. Toward a view of citizenship and lobbying: Corporate engagement in the political process. Business \& Society, 53: 260-299.

Ararat, M., Colpan, A. M., \& Matten, D. 2018. Business groups and corporate responsibility for the public good. Journal of Business Ethics, 153: 911-929.

Avi-Yonah, R. S. 2005. The cyclical transformations of the corporate form: A historical perspective on corporate social responsibility. Delaware Journal of Corporate Law, 30: 767-818.

Bansal, P., \& DesJardine, M. R. 2014. Business sustainability: It is about time. Strategic Organization, 12: 70-78.

Barney, J. 1991. Firm resources and sustained competitive advantage. Journal of Management, 17: 99-120.

Bernstein, S., \& Cashore, B. 2007. Can non-state global governance be legitimate? An analytical framework. Regulation and Governance, 4: 347-371.

Bitektine, A., \& Haack, P. 2015. The "macro" and the "micro" of legitimacy: Toward a multilevel theory of the legitimacy process. Academy of Management Review, 40: 49-75.

Boswell, J. 1983. The informal social control of business in Britain: 1880-1939. Business History Review, 57: 237-257.

Bowen, F., \& Aragon-Correa, J. A. 2014. Greenwashing in corporate environmentalism research and practice: The importance of what we say and do. Organization \& Environment, 27: 107-112.

Bowen, H. R. 1953. Social responsibilities of the businessman. New York: Harper \& Row.

Brès, L., Mena, S., \& Salles-Djelic, M.-L. 2019. Exploring the formal and informal roles of regulatory intermediaries in transnational multistakeholder regulation. Regulation \& Governance, 13: 127-140.

The B Team. 2018. A new bar for responsible tax: The B Team Responsible Tax Principles. Available at https://bteam.org/ our-thinking/news/responsible-tax.

Business Roundtable. 2019. Business roundtable redefines the purpose of a corporation to promote "an economy that serves all Americans." August 19: https://www. businessroundtable.org/business-roundtable-redefinesthe-purpose-of-a-corporation-to-promote-an-economy-thatserves-all-americans.

Carroll, A. B. 1979. A three dimensional model of corporate social performance. Academy of Management Review, 4: 497-505.

Carroll, A. B., Lipartito, K. P., Post, J. E., \& Werhane, P. H. 2012. Corporate responsibility: The American experience. New York: Cambridge University Press.

Carroll, C. E. 2011. Media relations and corporate social responsibility. In Ø. Ihlen, J. L. Bartlett, \& S. May (Eds.), Handbook of corporate social responsibility and communication: 423-444. Hoboken, NJ: Wiley Blackwell.

Carson, S. G., Hagen, Ø., \& Sethi, S. P. 2015. From implicit to explicit CSR in a Scandinavion context: The cases of HÅG and Hydro. Journal of Business Ethics, 127: 17-31.

Cashore, B. 2002. Legitimacy and the privatization of environmental governance: How non-state market-driven (NSMD) governance systems gain rule-making authority. Governance, 15: 503-529.

Cashore, B., \& Stone, M. W. 2012. Can legality verification rescue global forest governance? Analyzing the potential of public and private policy intersection to ameliorate forest challenges in Southeast Asia. Forest Policy and Economics, 18: 13-22.

Christensen, L. T., Morsing, M., \& Thyssen, O. 2013. CSR as aspirational talk. Organization, 20: 372-393.

Crane, A., Matten, D., \& Moon, J. 2008. Corporations and citizenship. Cambridge: Cambridge University Press.

Crane, A., Palazzo, G., Spence, L. J., \& Matten, D. 2014. Contesting the value of "Creating Shared Value." California Management Review, 56(2): 130-153.

Dahl, R. A. 1956. A preface to democratic theory. Chicago: University of Chicago Press.

Davis, K. 1960. Can business afford to ignore social responsibilities? California Management Review, 2(3): 70-76.

de Bakker, F. G. A., Rasche, A., \& Ponte, S. 2019. Multi-stakeholder initiatives on sustainability: A cross-disciplinary review and research agenda for business ethics. Business Ethics Quarterly, 29: 343-383.

Deephouse, D. L., Bundy, J., Tost, L. P., \& Suchman, M. 2017. Organizational legitimacy: Six key questions. In R. Greenwood, C. Oliver, T. Lawrence, \& R. Meyer (Eds.), 
The Sage handbook of organizational institutionalism (2nd ed.): 27-54. Thousand Oaks, CA: Sage.

Deephouse, D. L., \& Suchman, M. 2008. Legitimacy in organizational institutionalism. In R. Greenwood, C. Oliver, R. Suddaby, \& K. Sahlin (Eds.), The Sage handbook of organizational institutionalism: 49-77. Thousand Oaks, CA: Sage.

den Hond, F., \& de Bakker, F. G. A. 2007. Ideologially motivated activism. How activist groups influence corporate social change. Academy of Management Review, 32: 901-924.

DiMaggio, P. J., \& Powell, W. W. 1983. The iron cage revisited: Institutional isomorphism and collective rationality in organizational fields. American Sociological Review, 48: 147-160.

Djelic, M.-L., \& Etchanchu, H. 2017. Contextualizing corporate political responsibilities: Neoliberal CSR in historical perspective. Journal of Business Ethics, 142: 641-661.

Durand, R., Hawn, O., \& Ioannou, I. 2019. Willing and able: A general model of organizational responses to normative pressures. Academy of Management Review, 44: 299-320.

El Akremi, A., Gond, J.-P., Swaen, V., De Roeck, K., \& Igalens, J. 2018. How do employees perceive corporate responsibility? Development and validation of a multidimensional corporate stakeholder responsibility scale. Journal of Management, 44: 619-657.

Elankumaran, S., Seal, R., \& Hashmi, A. 2005. Transcending transformation: Enlightening endeavours at Tata Steel. Journal of Business Ethics, 59: 109-119.

Environics International. 1999. The Millennium Poll on Corporate Social Responsibility: Global public opinion on the changing role of companies. Available at https:// globescan.com/wp-content/uploads/2018/01/GlobeScan_ MillenniumPoll_1999_FullReport.pdf.

Fleming, P., \& Jones, M. T. 2012. The end of corporate social responsibility: Crisis \& critique. London: Sage.

Freeman, R. E. 2009. (First published in 1984.) Strategic management: A stakeholder approach. Cambridge: Cambridge University Press.

Freeman, R. E., Harrison, J. S., \& Wicks, A. C. 2007. Managing for stakeholders: Survival, reputation, and success. New Haven, CT: Yale University Press.

Friedea, G., Busch, T., \& Bassen, A. 2015. ESG and financial performance: Aggregated evidence from more than 2000 empirical studies. Journal of Sustainable Finance \& Investment, 5 : 210-233.

Friedman, M. 1970. The social responsibility of business is to increase its profits. New York Times Magazine, September 13: 32-33.

Gallie, W. B. 1955-1956. Essentially contested concepts. Proceedings of the Aristotelian Society New Series, 56: 167-198.

Gilbert, D. U., Rasche, A., \& Waddock, S. 2011. Accountability in a global economy: The emergence of international accountability standards. Business Ethics Quarterly, 21: 23-44.

Gjølberg, M. 2009. Measuring the immeasurable? Constructing an index of CSR performance in 20 countries. Scandinavian Journal of Management, 25: 10-22.
Glavas, A. 2016. Corporate social responsibility and employee engagement: Enabling employees to employ more of their whole selves at work. Frontiers in Psychology, 7(796): 1-10.

Gond, J.-P., Kang, N., \& Moon, J. 2011. The government of self-regulation: On the comparative dynamics of corporate social responsibility. Economy and Society, 40: 640-671.

Granovetter, M. 1985. Economic action and social structure: The problem of embeddedness. American Journal of Sociology, 91: 481-510.

Grayson, D., \& Kakabadse, A. 2013. Sustainable business leadership-Take it from the top. Ethical Corporation, February: 36-39.

Griffin, J. J., \& Mahon, J. F. 1997. The corporate social performance and corporate financial performance debate: Twenty-five years of incomparable research. Business \& Society, 36: 5-31.

Gutierrez Huerter O., G., Moon, J., Gold, S., \& Chapple, W. In press. Micro-processes of translation in the transfer of practices from MNE headquarters to foreign subsidiaries: The role of subsidiary translators. Journal of International Business Studies, 10.1057/s41267-019-00234-8.

Haack, P., Pfarrer, M. D., \& Scherer, A. G. 2014. Legitimacy-asfeeling: How affect leads to vertical legitimacy spillovers in transnational governance. Journal of Management Studies, 51: 634-666.

Hall, P. A. \& Soskice, D. (Eds.). 2001. Varieties of capitalism. Oxford: Oxford University Press.

Harris, S., Kim, C. H., Amaeshi, K., \& Suh, C. J. 2013. CSR and the national institutional context: The case of South Korea. Journal of Business Research, 66: 2581-259l.

Hart, S. L. 1995. A natural-resource-based view of the firm. Academy of Management Review, 20: 986-1014.

Hart, S. L., \& Milstein, M. 2003. Creating sustainable value. Academy of Management Executive, 17(2): 56-70.

Heald, M. 1970. The social responsibilities of business: Company and community: 1900-1960. Cleveland, OH: Case Western Reserve University Press.

Hiss, S. 2009. From implicit to explicit corporate social responsibility: Institutional change as a fight for myths. Business Ethics Quarterly, 19: 433-451.

Hofman, P. S., \& Moon, J., with Wu, B. 2017. Corporate social responsibility under authoritarian capitalism: Dynamics and prospects of state-led and society-driven CSR. Business \& Society, 56: 651-671.

Husted, B. W. 2015. Corporate social responsibility practice from 1800-1914: Past initiatives and current debates. Business Ethics Quarterly, 25: 125-141.

Ihlen, Ø., Bartlett, J. L., \& May, S. 2011. Corporate social responsibility and communication. In $\varnothing$. Ihlen, J. L. Bartlett, \& S. May (Eds.), Handbook of corporate social responsibility and communication: 3-22. Hoboken, NJ: Wiley Blackwell.

Jackson, G., \& Bartosch, J. 2016. Corporate responsibility in different varieties of capitalism: Exploring the role of national institutions. Gütersloh: Bertelsmann Stiftung. 
Jackson, G., Brammer, S., \& Matten, D. 2012. Corporate social responsibility and institutional theory. Socio-Economic Review, 11: 3-26.

Jamali, D., \& Karam, C. 2018. corporate social responsibility in developing countries as an emerging field of study. International Journal of Management Reviews, 20: 32-61.

Jamali, D., Osuji, F., \& Onyeka, K. (Eds.). In press. Corporate social responsibility in developing and emerging markets. Cambridge: Cambridge University Press.

Jones, D. A., Willness, C., \& Madey, S. 2014. Why are job seekers attracted by corporate social performance? Experimental and field tests of three signal-based mechanisms. Academy of Management Journal, 57: 383-404.

Kang, N., \& Moon, J. 2012. Institutional complementarity between corporate governance and corporate social responsibility: A comparative institutional analysis of three capitalisms. Socio-Economic Review, 10: 85-108.

Kaplan, R. 2014. Who has been regulating whom, business or society? The mid-20th-century institutionalization of "corporate responsibility" in the USA. Socio-Economic Review, 13: 125-155.

Kim, C. H., \& Moon, J. 2015. Dynamics of corporate social responsibility in Asia: Knowledge and norms. Asian Business \& Management, 14: 349-382.

Kinderman, D. 2012. "Free us up so we can be responsible!" The co-evolution of corporate social responsibility and neoliberalism in the UK, 1977-2010. Socio-Economic Review, 10: 29-57.

Knudsen, J. S., \& Moon, J. 2017. Visible hands: National government and international CSR. Cambridge: Cambridge University Press.

Knudsen, J. S., Moon, J., \& Slager, R. 2015. Government policies for corporate social responsibility in Europe: A comparative analysis of institutionalisation. Policy \& Politics, 43: 81-99.

Kolk, A., Kourula, A., Pisani, N., \& Westermann-Behaylo, M. 2020. The state of international business, corporate social responsibility and development: Key insights and an application to practice. In P. Lund-Thomsen, M. W. Hansen, \& A. Lindgreen (Eds.), Business and development studies: Issues and perspectives: 257-285. Abingdon, UK: Routledge.

Kostova, T., Roth, K., \& Dacin, M. T. 2008. Institutional theory in the study of multinational corporations: A critique and new directions. Academy of Management Review, 33: 994-1006.

Kostova, T., \& Zaheer, S. 1999. Organizational legitimacy under conditions of complexity: The case of the multinational enterprise. Academy of Management Review, 24: 64-81.

Kourula, A., Moon, J., Salles-Djelic, M.-L., \& Wickert, C. 2019. New roles of governments in the governance of business conduct: Implications for management and organizational research. Organization Studies, 40: 1101-1123.

KPMG 2017. The road ahead: The KPMG Survey of Corporate Responsibility Reporting. Available at https://home.kpmg/ uk/en/home/insights/2017/1 l/kpmg-international-survey-ofcorporate-responsibility-reporting-2017.html.
Kujala, J., Rehbein, K., Toikka, T., \& Enroth, J. 2013. Researching the gap between strategic and operational levels of corporate responsibility. Baltic Journal of Management, 8: 142-165.

Lawrence, J., Rasche, A., \& Kenny, K. 2015. Sustainability as opportunity: Unilever's sustainable living plan (2nd ed.). Case Centre, UK: Hult.

Maignan, I., \& Ralston, D. A. 2002. Corporate social responsibility in Europe and the U.S.: Insights from businesses' self-presentations. Journal of International Business Studies, 33: 497-515.

Mason, K., Chakrabarti, R., \& Singh, R. 2017. Markets and marketing at the bottom of the pyramid. Marketing Theory, 17: 261-270.

Matten, D., \& Crane, A. 2005. Corporate citizenship: Toward an extended theoretical conceptualization. Academy of Management Review, 30: 166-179.

Matten, D., \& Moon, J. 2008. "Implicit" and "explicit" CSR: A conceptual framework for a comparative understanding of corporate social responsibility. Academy of Management Review, 33: 404-424.

Matten, D., \& Moon, J. In press. The dynamics of CSR in a comparative perspective: Convergence towards divergent hybrids. In J. Ciulla \& T. Scharding (Eds.). Business ethics in troubled times. Berlin: Springer.

McBarnet, D. 2007. Corporate social responsibility beyond the law, through the law, for the law: The new corporate accountability. In D. McBarnet, A. Voiculescu, \& T. Campbell (Eds.), The new corporate accountability: Corporate social responsibility and the law: 9-56. Cambridge: Cambridge University Press.

McWilliams, A., \& Siegel, D. 2001. Corporate social responsibility: A theory of the firm perspective. Academy of Management Review, 26: 117-127.

Meyer, J. W., \& Rowan, B. 1977. Institutionalized organizations: Formal structure as myth and ceremony. American Journal of Sociology, 83: 340-363.

Midttun, A., Gjølberg, M., Kourula, A., Sweet, S., \& Vallentin, S. 2015. Public policies for corporate social responsibility in four Nordic countries: Harmony of goals and conflict of means. Business \& Society, 54: 464-500.

Mitchell, R. K., Agle, B. R., \& Wood, D. 1997. Toward a theory of stakeholder identification and salience: Defining the principle of who and what really counts. Academy of Management Review, 22: 853-886.

Mitra, N., \& Chatterjee, B. 2019. India and its corporate social responsibility mandate. Berlin \& Heidelberg: Springer.

Moon, J. 1995. The firm as citizen: Corporate responsibility in Australia. Australian Journal of Political Science, 30: 1-17.

Moon, J. 2002. Business social responsibility and new governance. Government and Opposition, 37: 385-408.

Moon, J. 2005. CSR in the UK: An explicit model of businesssociety relations. In A. Habisch, J. Jonker, M. Wegner, \& R. Schmidpeter (Eds.), CSR across Europe: 51-65. Berlin: Springer.

Moon, J., Crane, A., \& Matten, D. 2004. Can corporations be citizens? Corporate citizenship as a metaphor for 
business participation in society. Business Ethics Quarterly, 15: 429-453.

Moon, J., Murphy, L., \& Gond, J.-P. 2017. Historical perspectives on CSR. In A. Rasche, M. Morsing, \& J. Moon (Eds.), Corporate social responsibility: Strategy, communication and governance: 31-62. Cambridge: Cambridge University Press.

Moon, J., \& Sochacki, R. 1996. The social responsibility of business in job and enterprise creation: Motives, means and implications. Australian Quarterly, 68: 11-30.

Moon, J., \& Vallentin, S. 2019. Tax avoidance and corporate irresponsibility-CSR as problem or solution? In K. K. E. Elgaard, R. K. Feldthusen, A. Hilling, \& M. Kukkonen (Eds.), Fair taxation and corporate social responsibility: 19-51. Copenhagen: Ex Tuto.

Moore, C., Richardson, J. J., \& Moon, J. 1985. New partnerships in local economic development. Local Government Studies, 11(5): 19-33.

Okoye, A. 2009. Theorising corporate social responsibility as an essentially contested concept: Is a definition necessary? Journal of Business Ethics, 89: 613-627.

O'Sullivan, N., \& O'Dwyer, D. 2015. The structuration of issuebased fields: Social accountability, social movements and the Equator Principles issue-based field. Accounting, Organizations and Society, 43: 33-55.

Pasquero, J. 2004. Responsabilités sociales de l'entreprise: Les approches Nord-Américaines [Corporate social responsibility: North American approaches]. In J. Igalens (Ed.), Tous responsables [All responsible]: 257-272. Paris: Editions d'Organisation.

Pfarrer, M. D., DeCelles, K. A., Smith, K. G., \& Taylor, M. S. 2008. After the fall: Reintegrating the corrupt organization. Academy of Management Review, 33: 730-749.

Pierre, J. (Ed.). 2000. Debating governance: Authority, steering and democracy. Oxford: Oxford University Press.

Polanyi, K. 1957. The great transformation. Boston: Beacon Press.

Ponte, S. 2019. Business, power and sustainability in a world of global value chains. London: Zed Books.

Porter, M. E., \& Kramer, M. R. 2011. Creating shared value. Harvard Business Review, 89(1): 2-17.

Prahalad, C. K., \& Hart, S. L. 2002. The fortune at the bottom of the pyramid. Strategy+Business, 26: 1-14.

Preuss, L., Haunschild, A., \& Matten, D. 2006. Trade unions and CSR: A European research agenda. Journal of Public Affairs, 6: 256-268.

Rasche, A. 2009. A necessary supplement: What the UN Global Compact is and is not. Business \& Society, 48: 511537.

Rasche, A. 2019. More CEOs sacked for ethical failure than for poor financial performance. Business of Society, June 5: http://www.bos-cbscsr.dk/2019/06/05/ceos-ethical-failure/.

Rasche, A., de Bakker, F., \& Moon, J. 2013. Complete and partial organizing for corporate social responsibility. Journal of Business Ethics, 115: 651-653.
Rasche, A., \& Waddock, S. 2014. Global sustainability governance and the UN Global Compact: A rejoinder to critics. Journal of Business Ethics, 122: 209-216.

Reddy, C. D., \& Hamann, R. 2018. Distance makes the (committed) heart grow colder: MNEs' responses to the state logic in African variants of CSR. Business \& Society, 56: 562-594.

Reisch, L. A., \& Thøgersen, J. 2017. Research on sustainable consumption: Introduction and overview. In L. A. Reisch \& J. Thøgersen (Eds.), Handbook of research on sustainable consumption: 1-18. Cheltenham, UK: Edward Elgar.

Rossouw, D. 2005. Business ethics and corporate governance. Business \& Society, 44: 94-106.

Ruggie, J. G. 2002. The theory and practice of learning networks: Corporate social responsibility and the Global Compact. Journal of Corporate Citizenship, 5(Spring): 27-36.

Ruggie, J. G. 2004. Reconstituting the global public domain: Issues, actors and practices. European Journal of International Relations, 10: 499-531.

Rupp, D. E., Williams, C. A., \& Aguilera, R. V. 2010. Increasing corporate social responsibility through stakeholder value internalization (and the catalyzing effect of new governance): An application of organizational justice, selfdetermination, and social influence theories. In M. Schminke (Ed.), Managerial ethics: Managing the psychology of morality: 69-88. New York: Routledge.

Scherer, A. G., \& Palazzo, G. 2007. Toward a political conception of corporate responsibility: Business and society seen from a Habermasian perspective. Academy of Management Review, 32: 1096-1120.

Scherer, A. G., \& Palazzo, G. 2011. The new political role of business in a globalized world: A review of a new perspective on CSR and its implications for the firm, governance, and democracy. Journal of Management Studies, 48: 899-931.

Scherer, A. G., Palazzo, G., \& Seidl, D. 2013. Managing legitimacy in complex and heterogeneous environments: Sustainable development in a globalized world. Journal of Management Studies, 50: 259-284.

Scherer, A. G., Rasche, A., Palazzo, G., \& Spicer, A. 2016. Managing for political corporate social responsibility: New challenges and directions for PCSR 2.0. Journal of Management Studies, 53: 273-298.

Schmeltz, L. 2014. Identical or just compatible? The utility of corporate identity values in communicating corporate social responsibility. International Journal of Business Communication, 5: 234-258.

Seitanidi, M. M., \& Crane, A. 2014. Social partnerships and responsible business: $A$ research handbook. New York: Routledge.

Silberhorn, D., \& Warren, R. C. 2007. Defining corporate social responsibility: A view from big companies in Germany and the UK. European Business Review, 19: 352-372.

Srinivasan, V., \& Parvathy, V. In press. Human rights disclosures: $A$ study of select Indian firms. Working paper series, Indian Institute of Management Bangalore. 
Steurer, R. 2010. The role of governments in corporate social responsibility: Characterising public policies on CSR in Europe. Policy Sciences, 43: 49-72.

Strand, R., Freeman, R. E., \& Hockerts, K. 2015. Corporate social responsibility and sustainability in Scandinavia: An overview. Journal of Business Ethics, 127: 1-15.

Strine, L. E. 2014. Making it easier for directors to "do the right thing"? Harvard Business Law Review, 4: 235-254.

Suchman, M. C. 1995. Managing legitimacy: Strategic and institutional approaches. Academy of Management Review, 20: 571-610.

Suddaby, R., Bitektine, A., \& Haack, P. 2017. Legitimacy. Academy of Management Annals, 11: 451-478.

Tata, R. N., \& Matten, D. 2016. Corporate community involvement in the 2lst century. In D. Barton, D. Horvóth, \& M. Kipping (Eds.), Re-imagining capitalism: Towards a responsible, long-term model: 68-83. Oxford: Oxford University Press.

Taylor, I. 2014. Africa rising? BRICS-diversifying dependency. Oxford: James Currey.

Vallentin, S. 2015. Governmentalities of CSR: Danish government policy as a reflection of political difference. Journal of Business Ethics, 127: 33-47.

Vallentin, S., \& Spence, L. J. 2017. Strategic CSR: Ambitions and critiques. In A. Rasche, M. Morsing, \& J. Moon (Eds.), Corporate social responsibility: Strategy, communication and governance: 63-86. Cambridge: Cambridge University Press.

Vigneau, L., Humphreys, M., \& Moon, J. 2015. How do firms comply with international sustainability standards? Processes and consequences of adopting the Global Reporting Initiative. Journal of Business Ethics, 131: 469-486.

Vlachos, P. A., Panagopoulos, N. G., \& Rapp, A. 2014. Employee judgments of and behaviors towards corporate social responsibility: A multi-study investigation of direct, cascading, and moderating effects. Journal of Organizational Behavior, 35: 990-1017.
Votaw, D. 1972. Genius becomes rare: A comment on the doctrine of social responsibility Pt.l. California Management Review, 15(2): 25-31.

Waddock, S., \& Bodwell, C. 2004. Managing responsibility: What can be learned from the quality movement. California Management Review, 47(1): 25-37.

Whelan, G. 2017. Political CSR: The corporation as a political actor. In A. Rasche, M. Morsing, \& J. Moon (Eds.), Corporate social responsibility: Strategy, communication and governance: 136-153. Cambridge: Cambridge University Press.

Whiteman, G., Walker, B., \& Perego, P. 2013. Planetary boundaries: Foundations for corporate sustainability. Journal of Management Studies, 50: 307-336.

Whitley, R. (Ed.). 1992. European business systems. London: Sage.

Whitley, R. 1997. Business systems. In A. Sorge \& M. Worner (Eds.), The IEBM handbook of organizational behaviour: 173-186. London: International Thomson Business Press.

Whitley, R. 1999. Divergent capitalisms: The social structuring and change of business Systems. Oxford: Oxford University Press.

Whitley, R. 2002a. Business systems. In A. Sorge (Ed.), Organization: 178-212. London: Thomson Learning.

Whitley, R. (Ed.). 2002b. Competing capitalisms: Institutions and economies. Cheltenham, UK: Edward Elgar.

Wildavsky, A. 1973. If planning is everything, maybe it's nothing. Policy Sciences, 4: 127-153.

Witt, M. A. 2019. De-globalization: Theories, predictions, and opportunities for international business research. Journal of International Business Studies, 50: 1053-1077.

Witt, M. A., \& Redding, G. 2013. Asian business systems: Institutional comparison, clusters, and implications for varieties of capitalism and business systems theory. SocioEconomic Review, 11: 265-300.

Dirk Matten (DMatten@schulich.yorku.ca) holds the Hewlett-Packard Chair in CSR, Schulich School of Business, York University, and is a visiting professor at Copenhagen Business School and the Universities of London, Nottingham, and Sabanc1. He received his Ph.D. in international business (Dr. habil.) from Heinrich-Heine-University Düsseldorf. $\mathrm{He}$ is interested in business ethics, governance of digital technologies, and comparative management.

Jeremy Moon (jm.msc@cbs.dk) is professor of sustainability governance, Copenhagen Business School, and director of the CBS Sustainability Centre. He received his Ph.D. in politics from the University of Exeter. His research interests include CSR theory, comparative CSR, and business and governance. 
Copyright of Academy of Management Review is the property of Academy of Management and its content may not be copied or emailed to multiple sites or posted to a listserv without the copyright holder's express written permission. However, users may print, download, or email articles for individual use. 